\title{
Pattern of Religious Education with Inclusive Paradigm: Implications in the Construction and Practice of Learning in Senior High School
}

\author{
Moh. Roqib ${ }^{1}$, Inten Mustika Kusumaningtias ${ }^{2}$, Iis Sugiarti ${ }^{3}$ \\ \{mohammadroqib333@gmail.com ${ }^{1}$ \} \\ IAIN Purwokerto, 53126, Indonesia ${ }^{1,2,3}$
}

\begin{abstract}
This article describes and explores the pattern of inclusive religious education which focuses on implications in curriculum construction and learning praxis in high schools under the auspices of Islamic organizations in Purwoker to. The research data were obtained from observation, interview and documentation. The results showed that the construction of the Religious Education curriculum at SMA Diponegoro Purwokerto which was under the auspices of the Nahdlatul Ulama refers to the substance of religious teachings based on the holy book, as sunnah, ijma, qiyas, with a strong religious tradition and refers to the curriculum of the ministry of education by opening it wide variants of the opinions of scholars in their studies, so that they are more open to differences. Whereas at SMA Muhammadiyah 1 Purwokerto is more based on the basis of the text of the Koran and hadiths strictly with the curriculum construct oriented to the decision of the Muhammadiyah Tarjih Council, so that the practice of teaching also refers to the view of the organization. Meanwhile, at SMA IT Al Irsyad Al Islamiyyah Purwokerto it is based on efforts to pay attention to the middle ground in the basic context of the scriptures and religious traditions. The curriculum construct tends to converge between NU and Muhammadiyah, so that in practical learning it tends to open dialogues with various religious discourses.
\end{abstract}

Keywords: Religious Education, Inclusive Paradigm, Curriculum, Learning Praxis

\section{Introduction}

Lately there have been many "amok" phenomena that have troubled various religious groups. The Setara Institute notes that there are various cases related to SARA every year, including in 2010 there were 216 a ttacks on religious minorities, in 2011 there were 244 cases, in 2012 there were 264 cases, in 2013 there were 222 cases and 2014 there were 134 ca ses. [1] Another example, the case of expulsion of the Shia Sampang community in 2012 and the Muslim community in Tolikara in 2015, [2] and cases of violence a ga inst the Ahmadiyah community in 2018 [3]. This departs from differences in understanding, blind fanaticism, hatred, the stigma of being deceived, exacerbated by discrimination which ultimately leads to acts of anarchism.

Now intolerance has also entered the joints of education. Lembaga Kajian Islam dan Perdamaian (LaKIP), published in 2011, with respondents from junior high and high school students in Jabodetabek, noted that $50 \%$ of students supported violent methods in dealing with religious and morality conflicts. It is further strengthened by data on the level of intolerance and 
radicalism which can be seen from the willingness to take action such as the destruction of problematic places of worship ( $24.5 \%$ teachers, $41.1 \%$ students), destruction of house sor facilities for religiou s members who are considered heretical (22.7\% teachers, students $51,3 \%$ ), defending with weapons aga inst Muslims from threats of other religions (teachers 32.4\%, $43.3 \%$ ), and the destruction of nightclubs (teachers $28.1 \%$, students $58.0 \%$ ).

Based on the survey above, it indicates that religious education has not been able to achieve optimal lea rning objectives. Currently, religious learning tends to betextual and nomative, and stops at the cognitive aspects. Religious learning does not touch on sociological or fulfillment aspects in order to form a strong personality and arrive at a wareness rela ted to optimal life welfare.

In this case, religious teachers in their learning praxis have not touched the affective and psychomotor a spects of students [7]. The learning material does not include inclusive Islamic religious ma terial which is relevant to Indonesia's pluralistic conditions. Whereas education is one of the effective media to shape students' views, that diversity is a necessity that must be appreciated constructively [8].

Zuly Qodir in his book "Gerakan Sosial Islam: Manifesto Kaum Beriman" states that religious education at the senior secondary level has a big problem because it tends to lead to ideologicaland religious reinforcement so that it often produces sectarian graduates. [9]

Inclusive Islam in this case seeks to offer Islam as a religion that is Rahmatal lil'alamin. This inclusive paradigm is expected to be able to answer global issues such as pluralism, humanism, gender and so on. [10] Inclusive paradigm of religious education is education that is more inculcated in a wareness of an open attitude and avoids egocentric attitudes. The value of inclusive va lues is implied in educational pra xis to bring up a dialogical learning, not doctrinalnormative. This is quite important because the educational pattern applied by schools will affect students' religious understanding.

Therefore, in this study will be studied about religious education with an inclu sive paradigm and its implications for curriculum construction and learning praxis in high schools under Islamic organizations in Purwokerto, including SMA Diponegoro Purwokerto, SMA Muhammadiyah 1 Purwoketo and SMA IT Al. Irsyad Al Islamiy yah Purwokerto. The three schools represent quite a large variety of Islamic organizations in Indonesia.

\section{Method}

This study is a field research with a qualitative approach, [12] so that the whole process of exca vation, presentation and analysis of data using qualitative descriptive approach12 a nd using constructivist perspective, the researchers understand the meaning and interpretation of indigenous communities in various contexts [13]. In the process of extracting data, the researcher enters naturally and tries to find the key informant, then search is carried out snowball.

The subjects in this study include: school principals, curriculum staff, religious tea chers, and students. The research data were obtained through interview techniques, observation and document review. The interview guide is used in the form of an outline of the research theme to elaborate on the values, meanings and views of the informants [14].

In observation, all phenomena related to the context and focus of the research were recorded and documented so that da ta rela ted to inclusive education paradigms were found and their implications for curriculum con struction and learning praxis. The documentation method is used 
to support data mining. Data analysis techniques used in this research is the engineering model of Miles and Huberman [15], is the stage of data reduction, display data and verification or conclusions.

\section{Results and Discussion}

\subsection{Inclusive Paradigmatic Religious Education Patterns in Senior High Schools Under the Shade of Islamic Organizations in Purwokerto}

Humanizing is one of the main missions in life. In the humanization process, it cannot be separated from critical a wareness that has become human's natural potential. This gives humans the possibility to understand the rea lity of the world and crea te unique cultural structures. Humans exist not only within themselves, but their existence fills space and time in the dynamic reality of life [16]. Therefore education must be relevant to the reality that surrounds it.

In the context of religion, there a re people in Indonesia who adhere to Islam, Christianity, Hinduism, Buddhism, Catholicism, Confucianism and belief in God Almighty. Plura lism must be understood as a necessity that must be treated properly, so that it has positive implications for life. If it is rejected and not treated properly, it will ca use disintegration of the nation.

This is proven by the fact that in the field there are still many cases of conflict in the name of religion. The world of education is also inseparable from the target of doctrinal understanding of religious fundamentalism. This understanding tends to absolutism, textualism, extremism, and prioritizes religious symbols which often lead to anarchism [17]. This indicates that the religious education that is implemented has only touched the skin, it has not reached the appreciation of religion itself. In this ca se the teacher has a considerable influence on students' religious understanding. Therefore, religious education with an inclu sive paradigm is a effort to respond to these problems.

This inclusive paradigm education is in accordance with the view of the Koran on inclusive attitudes in religion, namely in Qs al-Baqarah (02): 62, which means: "Truly believers, Jews, Christians and people Shabiin people, whoever among them truly believes in Allah, the next day and do good deeds, they will receive a reward from God, have no worries for them, and neither will they be sad."[18]

Referring to the verse, an inclu sive attitude needs to be cultivated in a pluralistic society in order to create a harmonious life. As according to Nurcholis Ma djid that pluralism is in line on the theological basis, namely: pluralism is sunnatullah, recognition of rights the existence of other religions, sentences sawa' (common platform), and there is no compulsion in religion [19]. It is also relevant to help develop education in accordance with the national strategy based on the nation's philosophy of "Bhineka Tunggal Ika". The other normative basis is in Qs. AlMaidah: 48, Qs. Al-Nisa: 125, Qs. Yunus: 19, Qs. Al-Baqarah: 62, 112, 213, 256, Qs. AlKafirun:6, and Qs. Al-Nahl: 36.

The recognition of universal truth which is the meeting point of religions is expected to be able to encourage the appreciation of human values recommended by religion, namely a globaluniversal va lue. Religious kindness is seen from the seriou sness of a person to believe in God and the willingness to do good to others. In the context of plural community life, religious patterns that emphasize a humanitarian orientation need to be appreciated and emphasized [20]. Isla mic religious education has a strategic significance and contribution in efforts to cultivate a wa reness of plurality, truth, and multiculturalism in the current era. Religious education which 
tends to be reactive, a pologetic and not affirmative towards religiou s communities will actually boomerang for the adherents of the concerned religion. So, it is important to note that the function of Islamic educational institutions can position itself in the middle of a plurality of values and spiritual norms of society [21].

In Purwokerto, there are several educational institutions under the auspices of Islamic organizations, such as: SMA Diponegoro Purwokerto which is under the auspices of the Purwokerto Central Al Hidayah Foundation which is affilia ted with Nahdlatul Ulama, [22] SMA Muhammadiyah 1 Purwokerto which is affiliated with Muhammadiyah [23] and SMA (IT) Al Irsyad Al Islamiyyah Purwokerto which is under the auspices of the Al Irsyad Al Isla miyyah Islamic Organization.

As for the pattern of Islamic religious education in each of these schools tend sto follow the mission of the organization that oversees it. Although in the context of the curriculum it also refers to the Ministry of Religion which is then complemented with the hidden curriculum.

SMA Diponegoro Purwokerto, which is affiliated with Nahdlatul Ula ma, understands plura lity a s rea lity to be grateful for and care for as part of a dynamic life. The pattem of religious education with an inclu sive paradigm disseminated to students at SMA Diponegoro Purwokerto is a n education pattern that holds four main elements, namely tasamuh, tawassuth, tawa zun and i'tidal.

NU positions itself as an organization that tends to be moderate, taking a position in the middle. NU is referred to as the traditionalist circles, where they practice Islam with tra ditional and accommodating characteristics. Islam is interpreted not as a mere symbol, but Islam is interpreted substantially, as social ethics. As according to Gus Dur, Islam is not something static and Islamic teachings are not something that is- onetime, so it requires reformulation or reapplication. This means that the development of basic Islamic la w must a lways be tran slated contextually. Seeing this, the understanding of the religious phenomenon is an understanding that dialogue between a bsolu te universal and rela tively particular by constantly contextualizing the social of religious communities.

In this case, SMA Muhammadiyah Purwokerto sees that an inclusive a pproach in le arning Isla $\mathrm{m}$ is used to provide a wareness and deep appreciation of plural social realities. Essentially and perennial the institutional model, system, character and culture of education at SMA Muhammadiyah Purwokerto cannot be separated from the roots of Muhammadiyah ideology which serve as a normative basis and historical experience a s an empiricalbasis.

Muhammadiyah makes education as a part of the Islamic movement and da wah amar ma'ruf nahi munkar with the a im of upholding a nd upholding Islamic teachings towards a truly Isla mic society. The ideology of Muhammadiy ah is based on the Qur'an and Hadith which are formally compiled in the Preamble to the Articles of Association, Islamic Life Guidelines (PHI), Muhammadiyah Personality, Khitah Perjuangan, Matan Beliefs in Muhammadiyah's Ideals of Life (MKCH), a nd other supporting guidelines. ideological values [25]. Muhammadiyah does not close the way to ijtihad, and for that there is the Ta rjih Council.

In the context of education, Muhammadiyah organizes inclusive education education for all for students. This is evident from the in terview data a nd documentation obtained from SMA Muhammadiyah Purwokerto that almost $75 \%$ of the students who study at the school do not ha ve Muhammadiyah Islamic religiou s background. So, education with an inclusive paradigm is very necessary to be a pplied in schools to provide students with a view of life that the world is so dynamic. However, it also needs to be addressed, that there are Muhammadiyah circles who a re also considered difficult to accept differences in their development.

Islamic social organizations that are concerned about empowering Human Resources through education are also carried out by Al Irsyad Al Isla miyyah. This organization makes a 
big contribution to the development of education, because every branch establishment in a certain a rea is accompanied by the establishment of a school.

Since its establishment, Al-Irsyad Al-Isla miyyah has aimed to purify tawhid, worship and practice of Islam and is engaged in education and da'wah based on the Qur'an and Sunnah in order to realize the Muslim person and the Islamic community towards the pleasure of Allah [26]. Therefore, Al-Irsyad has established hundreds of formal schools and non-formal educational institutions throughout Indonesia, including in Purwokerto where there are $\mathrm{Al}$ Irsya deducational institutions from early childhood to high school level. At SMA IT Al Irsyad Al Islamiyyah Purwokerto itself, has a vision of becoming an exemplary Islamic school with high a chievements and a global perspective [27]. The school is part of the means to a chieve the vision and mission of Al Irsyad Al Isla miyyah which is described in the essence and mabadi of 'Al-Irsyad. The essence of Al-Irsyad is an Islamic association that aims to purify Islamic monotheism, worship and amaliyah.

Based on an interview with the Religion teacher at SMA IT Al Irsyad Al Islamiyyah Purwokerto, related to the inclusive paradigm of religious education in the school, it a lso emphasizes the morals of students to respect each other, and not hurt each other. In addition, students who study at the school also come from a variety of backgrounds in the Islamic orga nization. Therefore, an attitude of inclusiveness and mutual respect for one a nother is an important thing. Regarding religious learning in schools, rela ted to the internalization of values, it does take from the rules set by Al Irsyad Al Islamiyyah. So that the rules in $\mathrm{Al}$ Irsyad are included in learning.

Of the three schools that have different Islamic organizational affilia tions, namely NU, Muhammadiy ah and Al Irsyad Al Isla miyyah, the view is that this inclusive paradigm of Islamic education is essential, because life is in separable from the pluralistic realities of life. However, in term s of taking law and jurisprudence, which are a lso internalized in education, it does have differences that a re not impossible to influence students' views of pluralism itself and also its religious characteristics, both ex treme right (exclusive-radical), extreme left (liberal) or taking the path middle (moderate).

\subsection{Implications of Inclusive Paradigm Religious Education in Curriculum Construction and Learning Praxis}

Religious education with an inclusive paradigm encourages each individual to accept differences and be ready to build a civilization that is peaceful and comfortable to live in together. Religious education here has a strategic position and role as a medium for value dissemination and how to understand Islamitself. With various Islamic institutions emerging as the biological children of an Islamic social organization, this has implications for the construction of curricula and learning designed to achieve the goals of the Islamic organizations that support them. So that it gives rise to a distinctive style between Islamic educational institutions with one a nother.

Islamic Religious Education (PAI) at the high school level is a compulsory subject for all Muslim students. However, PAI in SMA which is under the auspices of Islamic community orga nizations both at SMA Muhammadiy ah Purwokerto and SMA IT Al Irsyad Al Isla miyyah Purwokerto in the construction of the curriculum is divided into several clumpsas in the concept of segmentation of PAI in madrasah. Among them are aqidah, morality, fiqh, al-Qur'an-hadiths and Islamic Cultural History. Meanwhile, in SMA Diponegoro Purwokerto, it becomes a unity in the PAI subject. 
Based on the concept of thinking in an inclusive Islamic paradigm, the main source of open understanding of religion is its theology (aqidah). Therefore, if we draw this concept to analyze the Islamic Religious Education (PAI) curriculum, then we can see it through a subjectacademic approach which is based on the systematization of each discipline, as in the PAI family mentioned above [28]. In addition, it can also use the additive approach, the contributions approach, and the transformation a pproach [29].

If SMA Diponegoro Purwokerto even refers to the Ministry of Education and Culture's curriculum in its curriculum construction it uses the additive approach, which is adding the principles of Ahlussunah Waljamaah. It can be seen that there is a segmentation of student material allocated to local content. In the faith, NU follows the thoughts developed by Abu Hasan al-Asy'ari and Abu Mansur al-Maturidi. The basics a re based on the Qur'an and Hadith, Ijma, and Qiyas. The amaliyah is integrated with cultural traditions and localities, such as getting used to tahlil, pilgrimage, reading maulid, Friday prayer services that blend with the community and so on. So that the moderate values have been internalized to students.

As for the practice of learning in the classroom, the teachers convey about the law of jurisprudence with various views of the schools. So that it will open students' thinking horizons and notget trapped in a monopolistic understanding. In the study of fiqh, it is also added to the siya sah figh which contains the concepts of nationality which have been exemplified at the time of the Prophet, friends or caliphs afterwards and then linking it to the multicultural state of Indonesia. So that it can counterbalance the discourse of the Caliphate State and religious radicalism. It is strengthened by giving examples and amtsal and arguments contained in the Koran and Hadith regarding the command to call for goodness.

The PAI curriculum at SMA Muhammadiyah Purwokerto is an integration between the curriculum from the Ministry of Education and Culture and the Ministry of Religion Curriculum. So that PAI is broken down into subjects such as Al-Qur'an-Hadith, Jurisprudence, Date, and Aqidah Akhlak. Associated with the inclusivism view, internalized in the lessons of date and aqidah-morals. The subject of dating by examining Isla m historically will imply openness and give a understanding of Islam rahmatan lil'alamiin.

In the subject of Aqidah-akhlak, material about the relationship between humans and God, humans and humans and Muslims and Muslims is presented. In this case the teacher emphasizes that in religion one must stick to the Qur'an and the Sunnah, but the religious attitude when dealing with people who have different religions must be able to respect and respect.

Apart from that, Muhammadiyah consistently promotes the preaching of amarma'rufnahi munkar. The Jurisprudence subject at SMA Muhammadiyah Purwokerto has also undergone an adjustment to the decision of the Tarjih Council, which is an institution that is authorized to carry out the ijtihad tradition and conduct studies of all Muhammadiyah acts of worship in accordance with the Qur'an and Hadith. However, in this case, students who study at SMA Muhammadiy ah do not only come from Muhammadiyah, but also many students from the NU circle, therefore in their learning praxis the teacher also gives the view that there are differences of opinion. The hidden curriculum is implemented in the daily habits of students

At SMA IT Al Irsyad Al Islamiyyah, the curriculum used is complementary between the Ministry of Education and Culture, Ministry of Religion and the local curriculum, adjusting Mabadi 'Al Irsyad. PAI subjects at the school a re divided into Aqidah, Hadith / Morals, Fiqh, Date and the Qur'an. The values taken from Mabadi 'Al Irsyad are internationalized in every subject. For example, the value of tasamuh. This is considered important because the school also a ccommodates students from various backgrounds of religious orga nizations.

Teachers at Al Irsyad claimed that Al Irsyad was very moderate, because in his practice part of it used the NU tradition and part of the Muhammadiyah tradition. For example, the 
Maulid Celebration held by NU circles, Al Irsyad also celebrated. The tarawih prayer of Al Irshad uses the opinion of 23 cycles, and if there are 11 cycles then it does not matter, because it is the practice of the sunnah. However, students who have a different background, when at school, must follow the Al Irsy ad culture.

The inclusiveness side of the Al Irsyad Al Islamiyyah IT High School is also reflected in the school rules, namely every student of SMA IT Al Irsyad Al Isla miy yah behaves fairly and politely to others, respects others, communicates with others without hurting, and is not ra cist. Every problem that occurs is resolved by promoting a behavior win-win solution a nd a spint of peace-loving.

So, it can be concluded that the three schools are trying to instill an inclusive attitude and internalize an attitude of respect and respect for every difference and promote peace-loving. However, the three schools have different sides, especially with re gard to the method of making law. So that implies curriculum and practical learning for students. It should be underlined that building a community or jam'iyyah is important but must be able to work together with others. Certain jam'iyyah certainly have internal privacy, but this should be respected and respected [30]. In this case the existing differences encourage mutuala ppreciation of the variousforms of values that exist and constructively dialogue with each other so as to form a civilsociety.

\section{Conclusion}

From the above discussion it can be concluded that both SMA Diponegoro Purwokerto, SMA Muhammadiy ah Purwokerto and SMA IT Al Irsyad Al Islamiyyah Purwokerto, even though they have different Islamic organizational affiliations, both view diversity as a necessity that should be appreciated positively as part of dynamic motion. The inculcation of values through Islamic religious learning with an inclusive paradigm is considered important to be implemented, so that religious learning does not stop at the cognitive aspect, but comes to appreciation and a s a wa of life.

The Islamic education pattern with an inclusive paradigm in each of these schools tends to adapt to the ideology of the Islamic organization that supports it. So, it cannot be denied that each of these schools has a different legal ba sis for enrichment. So that it is very supportive to influence students' views about diversity and also has implications for various curriculum constructions and learning praxis. The infiltration of inclusive understanding in the three schools was more predominantly implemented in the material of Aqidah-Akhlak and Tarikh. Meanwhile, the Fiqh material tends to be exclusive according to the view of the organization.

\section{Acknowledgement}

Thanks to colleagues who helped write this article, either directly or indirectly, to produce this article. Hopefully this article is usefultheoretically and practically. 


\section{References}

[1] S. Institute, "Toleransi Keberagaman Semu," 2015. [Online]. Available: https://setarainstitute.org/toleransi-keberagaman-semu/. [Accessed 7 October 2020].

[2] U. D. Kusumawati, "Tolikara, Persoalan Diskriminasi dan Kekerasan yang Mengendap," 24 July 2015. [Online]. Available: https://m.cnnindonesia.com/nasional/20150724030750-2067895/tolikara-persoalan-diskriminasi-dan-kekerasan-yang-mengendap. [Accessed 7 October 2020].

[3] A. Amindoni, "Penganut Ahmadiyah Dipersekusi Lagi, Penegakkan Hukum Tumpul?," 21 May 2018. [Online]. Available: https://www.google.com/amp/s/www.bbc.com/indonesia/indonesia44189085.amp. [Accessed 4 Nophember 2020].

[4] R. Jacson, Inclusive Study of Religious Education and World Views in School: Signpost From the Council of Europe, Swaden: University of Warwick Coventry, 2016, p. 18.

[5] A. M. Djafar, Intoleransi: Memahami Kebencian dan Kekerasan Atas Nama Agama, Jakarta: Elex Media Komputindo, 2018,pp. 211-212.

[6] R. Tuasikal, "Kelompok Millenial Terus Melawan Intoleransi dan Radikalisme," VOA Indonesia, 15 January 2019. [Online]. Available: https://www.google.com/amp/s/www.voaindonesia.com/amp/kelompok-millenial-terus-melawanintoleransi-dan-radikalisme/4743574.html. [Accessed 4 Nophember 2020].

[7] I. Rosyidi, Pendidikan Agama Beradigma Inklusif, Malang: UIN Malang Press, 2009, p. 51.

[8] M. Y. Yusuf, "Pendidikan Islam Inklusif-Multikultural dana Perspektif Teori Gestalt," Ta'allum, vol. 2, no. 2, p. 196, 2014.

[9] Z. Qodir, Gerakan Sosial Islam: Manifesto Kaum Beriman, Yogyakarta: Pustaka Pelajar, 2009, p. 295.

[10] Daimah, "Pendidikan Inklusif Perspektif QS. Al Hujarat Ayat 10-13 sebagai Solusi Eksklusivisme Ajaran di Sekolah," Al Thariqah, vol. 3, no. 1, p. 55, 2018.

[11] N. Sary, "Mencegah Paham Radikalisme pada Sekolah," Manthiq, vol. 2, no. 2, pp. 194 -195, 2017.

[12] L. J. Moleong, Metodologi Penelitian Kualitatif, Bandung: Rosdakarya, 2002, p. 3.

[13] S. B. Merriam, Qualitative Research, New York: Jossey-Bass, 2002, p. 4.

[14] Sugiyono, Metode Penelitian Kuantitatif, Kualitatif, R \& D, Bandung: Alfabeta, 2018, p. 320.

[15] L. J. Moleong, Metodologi Penelitian Kualitatif, p. 232.

[16] Daimah, "Pendidikan Inklusif Perspektif QS. Al-Hujarat Ayat 10-13," p. 15.

[17] N. Kurnialoh, "Pendidikan Islam Berbasis Inklusivisme dalam Kehidupan Multikultur," Jurnal Penelitian, vol. 10, no. 1, p. 204, 2016.

[18] D. A. RI, Al-Qur'an dan Terjemah, Bandung: CV. Penerbit J-Art, 2005, p. 11.

[19] N. Majid, Islam, Doktrin dan Peradaban, Jakarta: Gramedia Pustaka Utama, 2019, pp. 177-196.

[20] M. Arif, "Pendidikan Agama Islam Inklusif-Multikultural," Journal of Islamic Education, vol. 1, no. 1, p. 8, 2012.

[21] M. T. Chaer, "Pendidikan Inklusif dan Multukultur dalam Perspektif Hadis Nabi Saw.," Cendekia, vol. 14, no. 2, pp. 226-227, 2016.

[22] Y. Machmudi, History and Profile of Islamic Organization in Indonesia, Depok: PTTI, 2013, p. 86.

[23] Riezam, Muhammadiyah Kyai Dahlan's Great Initiative, Yogyakarta: UAD Publishing Agency, 2014 , p. 5.

[24] H. Bagir, Islam Tuhan Islam Manusia, Bandung: Mizan Media Utama, 2017, p. 130.

[25] H. Nashir, Kembali ke Ideologi Muhammadiyah, Yogyakarta: Suara Muhammadiyah, 2006, p. x.

[26] Z. Anshari, "Jejak Historis Al Irsyad Al Islamiyyah dan Kiprahnya dalam Pengembangan Pendidikan Islam," Akademika, vol. 14, no. 1, p. 43, 2020.

[27] Handbook of SMA IT Al Irsyad Al Islamiyyah School Year 2016/207,p. 2.

[28] A. Hermawan, "Islam Inklusif dalam Kurikulum Pendidikan Agama Islam di SLTP," JPA, vol. 16, no. 2, pp. 85-86, 2015.

[29] J. A. Bank, "Approaches to Multicultural Curriculum Reform," in Multicultural Education: Issue and Perspective, London, Allyn and Bacon Press, p. 237. 
[30] Eva Wollenberg, Jon Anderson, Citlalli Lopez, Though All Things Differ. Pluralism As A Basis for Coorperation in Forest, Bogor: Center For International Foresty Research, 2005, p. 10. 